\title{
Emergency, security and strategic autonomy in EU economic regulation
}

\author{
Jens Hillebrand Pohl ${ }^{1}$
}

Published online: 31 August 2020

(C) Europäische Rechtsakademie (ERA) 2020

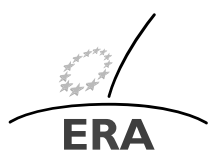

EUROPÄISCHE RECHTSAKADEMIE ACADEMY OF EUROPEAN LAW ACADEMIE DE DROIT EUROPEEN ACCADEMIA DI DIRITTO EUROPEO TRIER - TREVES - TREVIRI

The first half of 2020 witnessed two unrelated developments with far-reaching ramifications for the European Union. On 11 March, the World Health Organization (WHO) acknowledged that the outbreak of coronavirus disease 2019 (COVID-19) had reached pandemic proportions. ${ }^{1}$ Europe found itself at the heart of this unprecedented public health emergency, but struggled to come up with a unified response as Member States took matters in their own hands and-if only temporarily-rolled back 64 years of achievements in the matter of days, erecting severe restrictions on the rights and freedoms of European citizens. ${ }^{2}$

\footnotetext{
${ }^{1}$ WHO Director-General's opening remarks at the media briefing on COVID-19, 11 March 2020, available at https://www.who.int/dg/speeches/detail/who-director-general-s-opening-remarks-at-the-mediabriefing-on-covid-19-11-march-2020. Visited 2 July 2020.

${ }^{2}$ The European Commission resisted the introduction of intra-EU travel restrictions and a suspension of the Schengen travel area, see 'Coronavirus: EU rules out Schengen border closures amid Italy outbreak', 24 February 2020, Deutsche Welle, available at https://www.dw.com/en/coronavirus-eurules-out-schengen-border-closures-amid-italy-outbreak/a-52497811. Visited 2 July 2020. Austria was the first Member State to notify a temporary reintroduction of border control at an EU internal border pursuant to Article 25 et seq. of the Schengen Borders Code, in quick succession followed by Hungary, Czechia, Denmark, Poland, Lithuania and Germany, see https://ec.europa.eu/home-affairs/sites/homeaffairs/files/ what-we-do/policies/borders-and-visas/schengen/reintroduction-border-control/docs/ms_notifications_-reintroduction_of_border_control_en.pdf. Visited 2 July 2020. In the meantime, the plethora of national, regional and municipal restrictions on movement and other public health measures, as well as staff travel policies and cancellation of business travel, caused a collapse of the intra-EU air traffic system, prompting the urgent adoption of Regulation (EU) 2020/696 of the European Parliament and of the Council of 25 May 2020 amending Regulation (EC) No 1008/2008 on common rules for
}

J.H. Pohl

jpohl@era.int

1 Academy of European Law, Trier, Germany 
Less than two months later, on 5 May, crisis struck again. This time it was nothing less than the EU legal order, the central core of the European project, that was dealt a severe and humiliating blow before the highest constitutional authority of the most powerful Member State, the German Federal Constitutional Court, the Bundesverfassungsgericht (BVerfG). In its long-awaited judgment delivered on that day on the legality of the Public Sector Purchase Programme (PSPP) of the European Central Bank (ECB), the BVerfG declared a ruling by the European Court of Justice (ECJ) as ultra vires. ${ }^{3}$ By so ruling, the BVerfG defied the principle of the primacy of EU law and of the European Court of Justice (ECJ) as the final arbiter of that law. ${ }^{4}$

These twin crises of the first half of 2020 - the COVID-19 and the PSPP crisesare obviously of unrelated origin and fundamentally of very different nature. Yet, they coincide to strike at a most inopportune moment. The COVID-19 crisis has overshadowed and reshaped the original policy priorities of the von der Leyen Commission, notably the European Green Deal flagship project. ${ }^{5}$ The pandemic recovery efforts have understandably taken precedence over many other spending goals, both at Union and Member State levels, with the Commission having to both introduce new measures and fast-track certain original initiatives to kickstart the European recovery. ${ }^{6}$ The emergency has demonstrated the political primacy of public health over other, more aspirational policy priorities, and, more generally, the primacy of the Member States' shared interest in combatting threats to their security and public order. Does

the operation of air services in the Community in view of the COVID-19 pandemic, available at https://eur-lex.europa.eu/legal-content/EN/TXT/?uri=CELEX:32020R0696. Visited 2 July 2020.

${ }^{3}$ BVerfG, Judgment of the Second Senate of 05 May 2020 - 2 BvR 859/15 -, paras. 1-237, http://www. bverfg.de/e/rs20200505_2bvr085915en.html [ECLI:DE:BVerfG:2020:rs20200505.2bvr085915].

${ }^{4}$ On 10 May 2020, the European Commission announced that it was considering infringement proceedings against Germany with Commission President Ursula von der Leyen stating that 'the European Commission upholds three basic principles: that the Union's monetary policy is a matter of exclusive competence; that EU law has primacy over national law and that rulings of the European Court of Justice are binding on all national courts. The final word on EU law is always spoken in Luxembourg. Nowhere else.' See European Commission, Statement by President von der Leyen, 10 May 2020, available at https://ec.europa.eu/commission/presscorner/detail/en/statement_20_846. Visited 2 July 2020.

${ }^{5}$ European Commission, Adjusted Commission Work Programme 2020, COM(2020) 440 final, 27 May 2020, available at https://eur-lex.europa.eu/resource.html?uri=cellar\%3Af1ebd6bf-a0d3-11ea-9d2d01aa75ed71a1.0006.02/DOC_1\%26format=PDF.

${ }^{6}$ The recovery plan involves the European Commission raising 750 billion euro through new borrowing on the financial markets over the period 2021-2024; (slightly) reinforcing the long-term budget of the EU (the Multiannual Financial Framework) for 2021-2027 to 1100 billion euro (cf. 1087 billion euro proposed by the presidency of the European Council on 10 December 2019); the Commission raising up to 100 billion of loans to Member States on international financial markets under the temporary SURE instrument (Support to mitigate Unemployment risks in an Emergency); and the European Investment Bank making available guarantees and funding for businesses to the tune of 200 billion euro, see European Commission, Overview of the Commission's response, available at https://ec.europa.eu/ info/live-work-travel-eu/health/coronavirus-response/overview-commissions-response_en. Visited 2 July 2020. In addition, for euro area Member States, the European Stability Mechanism (ESM) is making available a new Pandemic Crisis Support tool of up to 240 billion euro subject to conditionality, see https://www.esm.europa.eu/content/europe-response-corona-crisis (visited 2 July 2020), while the ECB has introduced a temporary asset purchase programme of private and public sector securities called the Pandemic Emergency Purchase Programme (PEPP) up to a total of 1350 billion euro, see https://www.ecb.europa.eu/mopo/implement/pepp/html/index.en.html (visited 2 July 2020). 
this mean that the Green Deal is already a lost cause, or can it be salvaged or reinvented? That question will be briefly explored in the first part of this editorial.

The economic implications of the PSPP crisis are arguably even more serious to the long-term modus operandi of the Commission. Ever since the European sovereign debt crisis, the EU has grown accustomed — some might even say addicted—-to mobilising private capital through a variety of public-sector credit enhancements involving financial leverage, relying on the ECB as a lender of last resort. ${ }^{7}$ The last decade has seen vast sums being raised through various forms of leveraged finance, to which can be counted the bond-issuance programmes of the European Stability Mechanism and the European Fund for Strategic Investments. ${ }^{8}$ These programmes as well as the borrowing activities of the Member States directly rely on the backstop of the ECB's secondary-market bond-purchasing programmes, by means of which the ECB has subsidised Member States' borrowing costs through so-called quantitative easing (QE) to the tune of trillions of euro. ${ }^{9}$ The PSPP judgment throws into doubt the continued practice of QE and by extension the future of financial risk sharing among the Member States. ${ }^{10}$

Legally and politically, the PSPP ruling puts in doubt the legitimacy and authority of the EU legal order and the EU judiciary, again at a very inauspicious moment. ${ }^{11}$ It uncannily echoes recent tendencies towards de-judicialisation on the international plane, epitomised by the efforts of the United States to stymie the Appellate Body of the World Trade Organization, ${ }^{12}$ the rapid growth of interest in mediation and other non-adjudicative forms of dispute resolution in the area of investment disputes, ${ }^{13}$ the ECJ's Achmea case law holding that EU law is an non-arbitrable subject matter

\footnotetext{
${ }^{7}$ For an overview see, e.g., P. Cour-Thimann and B. Winkler (2016). Central Banks as Balance Sheets of Last Resort: ECB's Monetary Policy in a Flow-of-Funds Perspective. In: D. Cobham (Ed.) Monetary Analysis at Central Banks (Palgrave Macmillan: 2016).

${ }^{8}$ For a comprehensive summary, see M. Marchesi and M. Nava (2019) The EU Response to the Financial Crisis and the Economic Recession: The Juncker Plan, the Capital Markets Union, and the Banking Union. In: F. Allen, E. Faia, M. Haliassos and K. Langenbucher (Eds.) Capital Markets Union and Beyond (MIT Press 2019) (pp. 259-295).

${ }^{9}$ G. Claeys and A. Leandro (2016) The European Central Bank's Quantitative Easing Programme: Limits and Risks. Bruegel Policy Contribution 2016/04: https://www.econstor.eu/handle/10419/165969 (visited 2 July 2020).

${ }^{10}$ D. Sarmiento (2020) Requiem for Judicial Dialogue - The German Federal Constitutional Court's Judgment in the Weiss Case and its European Implications. EU Law Live Weekend Edition: https://eulawlive.com/app/uploads/weekend-edition-16.pdf (visited 2 July 2020).

${ }^{11}$ D. Kyriazis (2020) The PSPP judgment of the German Constitutional Court: An Abrupt Pause to an Intricate Judicial Tango. Blog post: https://europeanlawblog.eu/2020/05/06/the-pspp-judgment-of-thegerman-constitutional-court-an-abrupt-pause-to-an-intricate-judicial-tango/ (visited 2 July 2020).

${ }^{12}$ D. Abebe and T. Ginsburg (2019) The Dejudicialization of International Politics? Internatonal Studies Quarterly 63(6) (pp. 521-530); T. Payosova, G. Clyde Hufbauer and J. J. Schott (2018) The Dispute Settlement Crisis in the World Trade Organization: Causes and Cures. Policy Briefs PB18-5, Peterson Institute for International Economics.

${ }^{13}$ E. Shirlow (2019) The Rising Interest in the Mediation of Investment Treaty Disputes, and Scope for Increasing Interaction between Mediation and Arbitration. Blog post: http://arbitrationblog. kluwerarbitration.com/2016/09/29/the-rising-interest-in-the-mediation-of-investment-treaty-disputes-andscope-for-increasing-interaction-between-mediation-and-arbitration/?doing_wp_cron=1596727287. 9259729385375976562500 (visited 2 July 2020).
} 
in intra-EU investment treaty arbitration, ${ }^{14}$ and the British resistance towards adjudicative dispute settlement in the negotiations for a post-Brexit EU-UK trade agreement. ${ }^{15}$ It seems like the adjudication vogue of the last few decades has finally petered out and that politics and diplomacy is on the way back.

Whatever the legal, political and economic workarounds required to come to terms with the PSPP ruling, it is safe to conclude that the door is beginning to close on QE as a financial panacea. But, as the second part of this editorial argues, when one door closes, another opens up.

\section{COVID-19, public health and climate security: Europe qui protège 2.0?}

The EU is certainly no stranger to crises. One crisis has succeeded the next almost without pause for the last 15 years, ever since the rejection of the European Constitution by Dutch and French voters in the summer of $2005 .{ }^{16}$ The resolution of the latter through the entry into force of Treaty of Lisbon in late 2009 coincided almost exactly with the onset of the European sovereign debt crisis. Barely had that crisis subsided before Europe plunged into the migration crisis, tightly followed by Brexit and the rule-of-law crisis.

Constantly forced to reinvent itself, the EU has struggled throughout these crises to maintain a convincing narrative to justify its existential quest for unity. The vision of federalism has long lost its broad appeal and has proven no less divisive than that of European bonds, a eurozone budget and a common fiscal policy. The idea of a European cultural identity also does not seem like a very promising source of unity, to say the least. ${ }^{17}$ Even the 'safe' list of core values in Article 7 TEU has proven divisive, as evidenced both by the unresolved rule-of-law crisis and the gains of hard Eurosceptic and far-right parties in the European Parliament elections of 2019.

From these perspectives, the European Green Deal might at first glance have seemed like an unlikely lode star for the fissiparous Union. The plan to make Europe the first climate-neutral continent is not uncontroversial. Yet it links well with the enduring and uniting attraction of the 'European way of life' and could count on broad support across much of the political spectrum. Moreover, its ambitious agenda would also impose significant transition costs that would necessitate the injection of large-scale public spending into a struggling European economy and the mobilisa-

\footnotetext{
${ }^{14}$ J. H. Pohl (2018) Intra-EU Investment Arbitration after the Achmea Case: Legal Autonomy Bounded by Mutual Trust? European Constitutional Law Review 14(4) (pp. 767-791).

${ }^{15}$ M. Thimont Jack and J. Kane (2020) UK-EU Future Relationship Negotiations: Key Flashpoints. Blog post: https://www.instituteforgovernment.org.uk/explainers/future-relationship-negotiations-keyflashpoints (visited 2 July 2020).

${ }^{16}$ An excellent analysis of a 'Europe of crises' is provided by M. K. Davis Cross, The Politics of Crisis in Europe (Cambridge: 2017).

${ }^{17}$ T. Chopin (2018) Europe and the Identity Challenge: Who Are "We"? Blog post: https://www.robertschuman.eu/en/european-issues/0466-europe-and-the-identity-challenge-who-are-we (visited 2 July 2020).
} 
tion of both public and private investment, the total cost burden of which would be unevenly distributed among the Member States. ${ }^{18}$

The political feasibility of the European Green Deal thus crucially depends on the mobilisation of capital to finance the green transition ${ }^{19}$ and specifically on a model for financing which relies on the financial risk ultimately being shared among the Member States in proportion to their fiscal capacities. ${ }^{20}$ Put simply, Member States whose economies would incur large costs in transitioning to climate neutrality would be on the receiving end of the massive sustainable investment flows foreseen under the European Green Deal. As a political dividend, the resulting economic dependencies might also resolve the stand-off among Member States on such dead-end issues as migration and rule of law. ${ }^{21}$ An ambitious economic agenda can foster the economic interdependencies on which the Union relies for its unity. But such an agenda ultimately relies on financial risk sharing.

At first glance, the COVID-19 crisis seems to seriously, and perhaps fatally, undermine the European Green Deal or at least its timeline and political momentum. The pandemic has all-consuming of political attention and pushed other items lower on the political agenda. Faced with two grave crises — climate change and a public health emergency - it is intuitively understandable that the more acute crisis, the emergency, takes precedence. Yet, it does not imply that climate action could not be seen as linked to public health and that the turning the attention to one policy area necessarily comes at the expense of the other. A closer look reveals an important commonality between the two. Both public health and climate change can be considered essential priorities for security and public order. ${ }^{22}$ Emergency powers (exceptions, derogations etc.) are traditionally associated with such priorities, ${ }^{23}$ as can be gleaned from carve-outs in EU primary law. ${ }^{24}$ Should we expect an expanded 'soft security' concept to be the new grand narrative to link climate change with public health and perhaps other matters of ordre public, such as public morality, public order and public security? Will the COVID-19 trauma give rise to a new doctrine of Europe qui protège?

\footnotetext{
${ }^{18}$ F. Harvey and J. Rankin (2020) What is the European Green Deal and will it really cost $€ 1$ tn? News item: https://www.theguardian.com/world/2020/mar/09/what-is-the-european-green-deal-and-will-itreally-cost-1tn (visited 2 July 2020).

${ }^{19}$ European Commission (2020) Financing the green transition: The European Green Deal Investment Plan and Just Transition Mechanism. Policy brief: https:/ec.europa.eu/regional_policy/en/newsroom/news/ 2020/01/14-01-2020-financing-the-green-transition-the-european-green-deal-investment-plan-and-justtransition-mechanism (visited 2 July 2020).

${ }^{20}$ Ibid.

${ }^{21}$ A. Kluth (2019) Europe's Green Deal is Great, Unless it's a Back Door to a Planned Economy. News item: https://www.bloomberg.com/opinion/articles/2019-12-11/eu-green-deal-is-great-unless-it-s-abackdoor-to-planned-economy.

${ }^{22}$ J. Michaud (2014) Health Security and Foreign Policy. In: S. Rushton and J. Youde (Eds.) Routledge Handbook of Global Health Security (Routledge: 2014) (pp. 265-276); J. Barnett and W. N. Adger (2007) Climate Change, Human Security and Violent Conflict. Political Geography 26(6) (pp. 639-655).

${ }^{23}$ For a conceptual discussion, see C. Dupont (2018) The EU's Collective Securitisation of Climate Change. West European Politics 42(2) (pp. 369-390).

${ }^{24}$ See e.g. Articles 36, 45(3), 52(1), 65(1)(b) and 202 TFEU.
} 
Traditionally, the concept of security is associated with the survival of the state, its core values and the maintenance of law and public order. ${ }^{25}$ Public health falls within the concept of security. This link has been recognized by the European Commission with respect to the maintenance of critical health infrastructure, critical health technologies and the supply of critical health inputs, insofar as the disruption, failure, loss or destruction of such strategic assets would have a significant impact in a Member State or in the Union. ${ }^{26}$ Similarly, climate change has been identified as a threat to security and public order. ${ }^{27}$ Climate security is assumed to be correlated with a range of other security threats, including access to critical inputs and food security, natural disasters, migration and international conflicts. ${ }^{28}$

The threats of public-health emergencies and climate change are characterized by uncertainty and complexity, which put the survival and well-being of the state's population at risk and undermines law and public order, and which cannot be successfully be secured against through traditional geopolitical means. ${ }^{29}$ Thus, the European Green Deal fits well into a broader political narrative that centres on broad concept of security and on role of the state, and by extension, the Union in upholding the essential elements of the European way of life.

\section{The PSPP ruling and the return of industrial policy as an economic policy tool}

In essence, the PSPP ruling puts a limit to the ECB's monetary-policy backstop ${ }^{30}$ and reaffirms the participation of the Bundesbank, the German federal legislature and federal government in questions of deployment of QE, ${ }^{31}$ placing the onus on the ECB to justify its activities under its treaty mandate. ${ }^{32}$ The BVerfG judgment did not rule

${ }^{25}$ B. Buzan, O. Waever and J. de Wilde, Security: A New Framework For Analysis (Lynne Rienner: 1998) (pp. 21-23).

${ }^{26}$ European Commission (2020) Guidance to the Member States Concerning Foreign Direct Investment and Free Movement of Capital from Third Countries, and the Protection of Europe's Strategic Assets, Ahead of the Application of Regulation (EU) 2019/452 (FDI Screening Regulation), Communication from the Commission, C(2020) 1981 final.

${ }^{27}$ S. Kalliojärvi (2019) Age of Changes: Threat of Climate Change and Its Meaning for Security. In: L. Heininen and H. Exner-Pirot (Eds.) Climate Change and Arctic Security (Springer: 2019) (pp. 9-32).

${ }^{28}$ Ibid.

${ }^{29}$ L. Retter, E. Frinking, S. Hoorens, A. Lynch, F. Nederveen and W. Philips (2020) Relationships Between the Economy and National Security: Analysis and Considerations for Economic Security Policy in the Netherlands. RAND Europe (pp. 21-25); J. Castro Pereira (2015) Environmental Issues and International Relations, a New Global (Dis)Order - The Role of International Relations in Promoting a Concerted International System. Revista Brasileira de Política Internacional 58(1) pp. 191-209.

${ }^{30}$ A. Viterbo (2020) The PSPP Judgment of the German Federal Constitutional Court: Throwing Sand in the Wheels of the European Central Bank. European Papers 5(1) pp. 671-685.

${ }^{31}$ Europagruppe Grüne webinar 'After the ECB Judgement of the German Constitutional Court: Is EU Community Law in Jeopardy?' (18 June 2020). Panel debate with P. M. Huber, U. Šadl, M. Poiares Maduro and J. Henarowicz-Sikora.

${ }^{32}$ P. Bofinger, M. Hellwig, M. Hüther, M. Schnitzer, M. Schularick and G. B. Wolff (2020) The Independence of the Central Bank at Risk. Policy brief: https://www.bruegel.org/2020/06/theindependence-of-the-central-bank-at-risk/ (visited on 2 July 2020). 
out ECB's purchase programmes as such. Nor is the BVerfG's interpretation and application of EU law binding as a matter of EU law; the ruling is binding as a matter of German constitutional law. The force of the ruling beyond Germany's borders comes from the 'power of fact' rather than the power of law: the purchase programmes crucially depend on the continued participation of Germany which thus retains a de facto veto. ${ }^{33}$ The practical effect of the ruling is to place monetary financing on the same footing as fiscal financing, i.e. as matters reserved for the sovereign discretion and intergovernmental diplomacy of the Member States.

As a matter of political reality, as fiscal and monetary policy tools have now become less readily available to further the causes of the Union, other economic policy tools appear comparatively more available and potentially attractive. These are principally the economic tools of external and internal trade and investment policy; policy areas that more firmly within Union mandate, as they are exclusive competences. ${ }^{34}$

Is it imaginable that the PSPP ruling could nudge EU economic policymakers further away from the prevailing Keynesian and monetarist orthodoxy of demand and supply stimulus and give a new lease of life to the Ordoliberal credo: to foster a structurally-healthy legal environment for the economy? Can the Commission's New Industrial Policy for Europe, ${ }^{35}$ published on 10 March 2020, be seen as a small but significant step in such a direction?

The global context matters. A global trade war is raging between the two most powerful economies, the United States and China, with Europe caught in the middle, unsure of its future role. ${ }^{36}$ Should we follow the path of our traditional ally in the West and be drawn into what would become a 'trade world war'? And if we emulate our ally, what would a Europe First policy look like? ${ }^{37}$ Or should we stick to our multilateralist principles and make common cause with China even if it means compromising on our core democratic values and our commitment to fundamental civil

\footnotetext{
${ }^{33}$ See, e.g., F. Canepa and B. Koranyi (2020) ECB Prepares for the Worst: Life Without the Bundesbank. News item: https://www.reuters.com/article/us-ecb-policy-bundesbank-exclusive/exclusive-ecb-preparesfor-the-worst-life-without-the-bundesbank-sources-idUSKBN2321M7 (visited 2 July 2020); M. Weber (2020) The German Court Ruling Against ECB Asset Purchases Doesn't Make Economic Sense. Blog post: https://blogs.lse.ac.uk/businessreview/2020/05/12/the-german-court-ruling-against-ecbasset-purchases-doesnt-make-economic-sense/ (visited 2 July 2020).

${ }^{34}$ Articles 3(1)(e) and 207(1) TFEU.

${ }^{35}$ European Commission, A New Industrial Strategy for Europe, 10 March 2020, COM(2020) 102 final (New Industrial Strategy).

${ }^{36}$ See, e.g., the various contributions in B. Lippert and V. Perthes (Eds.) Strategic Rivalry Between United States and China. SWP Research Paper: https://www.swp-berlin.org/fileadmin/contents/products/ research_papers/2020RP04_China_USA.pdf (visited on 2 July 2020); T. Liu and W. T. Woo (2018) Understanding the U.S.-China Trade War. China Economic Journal 11(3) pp. 319-340; P. Blustein (2019) Schism: China, America and the Fracturing of the Global Trading System. Centre for International Governance Innovation; P. A. G. van Bergeijk (2019) Deglobalization 2.0: Trade and Openness During the Great Depression and the Great Recession. (Edward Elgar).

${ }^{37}$ J. Shapiro and D. Pardijs (2017) The Transatlantic Meaning of Donald Trump: a US-EU Power Audit. Blog post: https://www.ecfreu/publications/summary/the_transatlantic_meaning_of_donald_trump_a_us _eu_power_audit7229 (visited on 2 July 2020).
} 
rights $?^{38}$ Or should we stick our heads in the sand hoping that a return to the seemingly uncomplicated pre-Trump status quo ante bellum will one day re-emerge? ${ }^{39}$

The multilateral trading system has been in a state of suspended animation since December 2019 when the membership of the Appellate Body of the WTO fell below the minimum three which are necessary to hear a case. ${ }^{40}$ The longer the absence of an enforcement mechanism lasts the greater the likelihood that the WTO will remain disregarded in favour of regional and bilateral trade agreements. This would point towards continued unilateralism on trade policy. Indeed, China and the United States have introduced numerous restrictive trade measures in a conflict that does not respect the neat categorization into established policy areas. ${ }^{41}$

Europe's New Industrial Strategy reaffirms the EU's commitment to the multilateral trading system, but at the same time moves in the direction of strategic autonomy. ${ }^{42}$ The Strategy is presented as facilitating the 'twin transition' towards climate neutrality and digital leadership. ${ }^{43}$ The achievement of that policy agenda has both an external and an intra-EU dimension.

Externally, the Strategy foresees enhanced trade enforcement with the creation of a 'Chief Trade Enforcement Officer' seemingly mimicking the office of the U.S. Trade Representative. ${ }^{44}$ It includes a reinforced anti-subsidies trade-defence instrument ${ }^{45}$ and customs controls. ${ }^{46}$ Trade defensive in nature is also the proposed Carbon Border Adjustment Mechanism that is designed to ensure that non-EU imports and EU domestic production are in carbon-neutral competition. ${ }^{47}$

The European Green Deal itself is set to play an important role as an assertive trade policy instrument. Standard setting in the area of social, labour and environmental regulation is expressly mentioned as means for 'Europe to project its values' ${ }^{48}$ The

\footnotetext{
${ }^{38}$ L. Odgaard and S. Biscop (2006) The EU and China: Partners in Effective Multilateralism? Conference paper: http://www.egmontinstitute.be/content/uploads/2014/01/Odgaard-Biscop-EU-China.pdf?type=pdf (visited on 2 July 2020); B. Hellendorff and T.N. Rühlig (2020) The EU's Reactive Approach to Rising Tension Between the US and China. In: M. Esteban and M. Otero-Iglesias (Eds.) Europe in the Face of US-China Rivalry. Report by the European Think-tank Network on China (ETNC): https:// www.ifri.org/sites/default/files/atoms/files/etnc_report_us-china-europe_january_2020_complete.pdf (visited on 2 July 2020); F. J. Gómez Martos (2019) Multilateralism Chinese Style. Policy brief: https://www.robert-schuman.eu/en/european-issues/0540-multilateralism-chinese-style (visited on 2 July 2020).

${ }^{39}$ A. Narlikar (2020) Why Multilateralism Is in Such a Mess and How We Can Fix It. Blog post: https:// www.weforum.org/agenda/2020/01/why-multilateralism-is-in-such-a-mess-and-how-we-can-fix-it/ (visited on 2 July 2020).

${ }^{40}$ T. Payosova, G. Clyde Hufbauer and J. J. Schott (2018) The Dispute Settlement Crisis in the World Trade Organization: Causes and Cures. Policy Briefs PB18-5, Peterson Institute for International Economics.

${ }^{41}$ D. Wong and A. Chipman Koty (2020) The US-China Trade War: A Timeline. Blog post: https://www. china-briefing.com/news/the-us-china-trade-war-a-timeline/ (visited 2 July 2020).

${ }^{42}$ New Industrial Strategy (fn 35 above), p. 3.

${ }^{43}$ Ibid.

${ }^{44}$ Ibid., p. 7.

${ }^{45}$ Ibid., p. 6.

${ }^{46}$ Ibid., p. 7.

${ }^{47}$ Ibid., p. 8.

${ }^{48}$ Ibid., p. 2.
} 
external aspect of the Green Deal is that EU environmental sustainability standards will be mandatory for EU firms' global supply chains. ${ }^{49}$ EU businesses will have to account for the sustainability compliance of its foreign subsidiaries, affiliates and trading partners, not only with respect to the trade in goods, but also service contractors. ${ }^{50}$ The Green Deal thus introduces potentially extensive non-tariff barriers to trade. ${ }^{51}$ If the WTO dispute settlement system was functioning, such barriers might be challenged before panels and the Appellate Body, but they might also be justified under WTO law. ${ }^{52}$ In any event, without a functioning WTO dispute settlement system, these questions will be left unresolved. It is also possible that this new 'green compliance burden' might level the playing field as between EU and non-EU suppliers in some economic sectors and encourage import substitution that would stimulate the European economy. ${ }^{53}$

With respect to intra-EU economic policy, the New Industrial Strategy comprises two main strands of planned efforts: to attain EU industrial and strategic autonomy, and to promote intra-EU competitiveness and innovation:

Europe's strategic autonomy is about reducing dependence on others for things we need the most: critical materials and technologies, food, infrastructure, security and other strategic areas. They also provide Europe's industry with an opportunity to develop its own markets, products and services which boost competitiveness. ${ }^{54}$

These efforts bring to mind Europe's endemic shortcomings on the global tech scene. The today's business buzz words-GAFAs ${ }^{55}$ and BATs ${ }^{56}$ - conceal not a single European enterprise, with European start-ups being notably absent among the naturally monopolistic platforms for social media and e-commerce. At the same time, the Strategy's intra-EU dimension also represents a realisation of the EU's vulnerability to external disruption of global trade and investment flows and its dependence on third countries for certain critical technologies, infrastructure and inputs, particularly energy and raw materials. Europe is poorly prepared for a total collapse in global trade and investment—whatever its probability—, such as might be the case in an escalating global conflict, perhaps involving cyber or hybrid warfare, among its major

\footnotetext{
${ }^{49}$ B. Fox (2020) New Human Rights Laws in 2021, Promises EU Justice Chief. News item: https:// www.euractiv.com/section/global-europe/news/new-human-rights-laws-in-2021-promises-eu-justicechief/ (visited 2 July 2020).

${ }^{50}$ Ibid. See also B. Warwas (2020) EU Rules and Values, Transnational Legal Ordering, and International Arbitration. In: M. Cantero Gamito and H.-W. Micklitz (Eds.) The Role of the EU in Transnational Legal Ordering: Standards, Contracts and Codes (Edward Elgar: 2020) (pp. 80-99).

${ }^{51}$ I. Espa and G. Marín Durán (2020) Promoting Green Energy Through EU Preferential Trade Agreements: Potential and Limitations. Legal Issues of Economic Integration 47(2) pp. 115-150. 52 Ibid.

${ }^{53}$ For a similar discussion, see United Nations (2017) Green Industrial Policy: Concept, Policies, Country Experiences. Policy brief: https://wedocs.unep.org/bitstream/handle/20.500.11822/22277/ Green_industrial_policy.pdf?sequence=1\%26isAllowed=y (visited on 2 July 2020).

${ }^{54}$ New Industrial Strategy (fn 35 above), p. 13.

${ }^{55}$ Google, Apple, Facebook and Amazon.

${ }^{56}$ Baidu, Alibaba and Tencent. To these 'Asian GAFAs' can also be counted Xiaomi and Samsung.
} 
trading partners. Without strategic capabilities to endure an economic emergency, Europe's political autonomy in such a situation might be compromised, which poses a risk to the EU's survival. The security and public order of the EU also require an ability to retain and mobilise financial resources in a situation of disrupted global investment flows.

The initiatives mentioned in the Strategy to promote strategic autonomy can be divided into efforts to retain existing critical resources and strategic assets and efforts to develop or secure critical capabilities and supplies in strategic areas where such resources and assets are lacking. Of the first type of efforts, specific mention is made of the EU's recently introduced framework for inward investment screening. ${ }^{57}$ The second type of efforts comprises safeguarding strategic digital infrastructures, which involves cybersecurity of $5 \mathrm{G}$ networks, ${ }^{58}$ enhanced industrial capacity in digital infrastructure with investment for $5 \mathrm{G}$ and $6 \mathrm{G}$ networks,${ }^{59}$ development of a critical quantum communication infrastructure and other key enabling technologies, including robotics, microelectronics, high-performance computing and data cloud infrastructure, blockchain, quantum technologies, photonics, industrial biotechnology, biomedicine, nanotechnologies, pharmaceuticals, advanced materials and technologies. ${ }^{60}$

Building strategic economic autonomy also involves securing supply of critical inputs for industry, notably energy and raw materials, notably those that are crucial for markets such as e-mobility, batteries, renewable energies, pharmaceuticals, aerospace, defence and digital applications, ${ }^{61}$ as well efforts to boost recycling and use of secondary raw materials. ${ }^{62}$ Specific mention is made of the availability, affordability, sustainability and security of supply of pharmaceuticals, as highlighted by the COVID-19 crisis. $^{63}$

The second strand of the Strategy's intra-EU economic policy aspect includes the establishment of a Single Market Enforcement Task Force, ${ }^{64}$ an Intellectual Property Action Plan aiming, among other things, to 'uphold and strengthen Europe's tech sovereignty', an updated competition policy and revised state aid rules. ${ }^{65}$ It also includes an SME Strategy and other efforts to develop an EU data economy, ${ }^{66}$ efforts to stimulate investment critical technologies, notably artificial intelligence, 5G, data and metadata analytics, ${ }^{67}$ and the European Strategy for Data which envisages framework

\footnotetext{
${ }^{57}$ New Industrial Strategy (fn 35 above), pp. 2, 13.

${ }^{58}$ Ibid.

${ }^{59}$ Ibid., p. 4.

${ }^{60}$ Ibid., p. 13 .

${ }^{61}$ Ibid., p. 14.

${ }^{62}$ Ibid.

${ }^{63}$ Ibid.

${ }^{64}$ Ibid., p. 5

${ }^{65}$ Ibid.

${ }^{66}$ Ibid.

${ }^{67}$ Ibid., p. 4. 
for businesses to create, pool and use data to improve their competitiveness, intra-EU and externally. ${ }^{68}$

The answer to the question whether the New Industrial Strategy heralds a shift away from fiscal and monetary stimulus policies depends crucially on how the Strategy's envisaged policy initiatives are to be financed. Nothing in the Strategy indicates a rejection of budget-deficit stimulus or QE as ordinary policy tools. However, there are three interesting areas in the Strategy that suggest a possible change of course.

First, in the context of eliminating barriers to cross-border business operations in the single market, the Strategy mentions the urgency of tax harmonisation and the creation of a common consolidated corporate tax base. ${ }^{69}$ Such a move would be a step towards increased fiscal prudence and away from deficit spending and harmful intra-EU tax competition.

Second, as means of financing large-scale projects, the Strategy encourages the formation of industrial alliances, bringing together investors, governments, institutions and industrial partners to identify technology needs, investment opportunities and regulatory barriers and enablers. ${ }^{70}$ The Strategy cites successful examples in the area of batteries, plastics and microelectronics and proposes further alliances in the area of clean hydrogen, low-carbon industries, industrial clouds and platforms, and raw materials. With respect to the defence and space sectors, the Strategy goes a step further and recommends the consolidation of Europe's fragmented defence industry to secure Europe's ability to build the next generation of critical defence capabilities. $^{71}$ It also recommends exploring synergies between civil, space and defence industries in EU programmes to make more effective use of resources and technologies and create economies of scale. ${ }^{72}$

Third, the new Action Plan on the Capital Markets Union represents the Strategy's most concrete initiative addressing strategic investment autonomy, including the strengthening of intra-EU investment protection and efforts to unlock more diverse sources of funding for European businesses, especially SMEs. ${ }^{73}$ An intra-EU framework for private-sector investment is currently lacking beyond the general provisions of primary EU law.

\section{Epilogue}

There are reasons to be cautiously optimistic about the von der Leyen Commission's policy agenda post-COVID-19. The notion of European security and of a Europe that protects, whether in matters of public health, climate change, core values, geopolitics or the European way of life, is capable of providing a strong and compelling political narrative to maintain unity among the diversity of Member States. If

\footnotetext{
${ }^{68}$ Ibid.

${ }^{69}$ Ibid., p. 5.

${ }^{70}$ Ibid., p. 10, 15.

${ }^{71}$ Ibid., p. $13 \mathrm{f}$.

${ }^{72}$ Ibid., p. 14.

${ }^{73}$ Ibid., p. 12.
} 
so, the COVID-19 has accentuated, by means of powerful example, the overarching policy direction of the Commission, rather than distracted from it.

As disastrous as the PSPP ruling may be to adherents of fiscal and monetary stimulus policies, it actually represents an opportunity to pause and consider other economic policy tools, notably the long-discredited notion of industrial policy. A turn towards the latter would imply a return of fiscal and monetary policy to its rightful roles of passively supporting economic development, rather than fuelling, what is often not so much development, but inflation and financial instability. It is also possible to envisage that a reduced dependency on monetary financing will shift emphasis towards capital mobilization through efforts to control the mobility of the fiscal base and by extension the monetary base. Such a development is also associated with the reconceptualisation of money made possible through distributed ledger technology.

Europe's strategic policy choices in the area of economic policy depends also on the balance of interests of its Member States in the face of global developments. A continued retreat of multilateralism, further decline in global trade and investment flows and a return to geoeconomics will certainly harm Europe's global exports. European exporters would have to find new markets closer to home. At the same time, import substitution may give a welcome new lease of life to Europe's under-employed regions and benefit regions and Member States that enjoy comparative trade advantages such as well-trained workforces, efficient public administration, low energy costs and developed infrastructure. Making full use of the internal market of 450 million consumers to compensate for a fall in world trade and investment would create new economic interdependencies among the Member States and rebalance their economic relations.

Publisher's Note Springer Nature remains neutral with regard to jurisdictional claims in published maps and institutional affiliations. 